\title{
Academic Freedom: Norms, Methods, Contestations
}

\section{Doug Steward}

The author is associate

director of programs and

$A D E$ at the MLA.

$A$ version of this article

was presented at the

2008 MLA convention

in San Francisco.
THERE is a common misconception among faculty members that academic freedom is a species of first amendment right belonging to individual faculty members who are thereby protected from administrative or governmental reprisal in any speech at any time. The legal and academic history of academic freedom does not support such an understanding of academic freedom. As Robert Post has argued, "no university currently deals with its faculty as if academic freedom were an individual right"; instead, faculty members are subject to disciplinary review (78). At every stage in scholars' careers, their practices_-including teaching and student learning — are subject to "a normative account of the kind and nature of relevant professional knowledge." In Post's view, the necessity of a professional judgment of relevance according to established disciplinary norms "strongly suggests that the distinction between education and indoctrination is largely internal to academic standards" and that it must therefore remain a corporate responsibility of the faculty, not the purview of an individual (81). Faculty members are hired to work in programs of teaching and scholarship that they also collectively shape and evaluate. Entry to the faculty is contingent-I use the word advisedly in this context — on whether applicants meet disciplinary standards and find an institutional situation in which they and their research "fit." These contingencies are enormously problematic and complex, but for the moment I want only to emphasize the corporate responsibility for and protection afforded by membership in the faculty, however we define that term. For its part, the American Association of University Professors' canonical assertion of faculty rights urges that faculty members "are entitled to full freedom in research and in the publication of the results," but it is quick to add that "their special position in the community imposes special obligations" where accuracy, restraint, and respect are concerned.

The faculty's corporate responsibility for its composition and work can provide powerful protection to faculty members who undertake controversial work, as scholars had already discovered in the medieval European university (Hofstadter 3-11). On the other hand, such responsibility might also be construed, Joan Scott reminds us, to imply "that in order to protect the autonomy of the teaching establishment from 'outside' interference, [the teaching establishment] had to clean its own house by purging politically suspect teachers. On this definition, the greater good of the profession required the sacrifice of its most unconventional or troublesome members" (164). This is precisely the fear that certain activist groups hope to instill in a critical mass of faculty members: a sense that they must, if they wish to protect their own intellectual freedom, suppress the contestatory work of those who attract external irritants (Steward). Because academic freedom is a function of and entrusted to the corporate faculty, defenses of academic freedom must be articulated in the terms of curricula that are thoughtfully constructed according to disciplinary norms. But this potentially powerful system of protection is weakened when the faculty has little

ADFL and the Association of Departments of Foreign Languages are trademarks owned by the Modern Language Association. (c) 2011 by the Association of Departments of Foreign Languages, CrossRef DOI: 10.1632/adfl.41.3.33, ISSN 0148-7639 
Academic Freedom:

Norms, Methods,

Contestations

Doug Steward sense of how its curriculum fits together and how individual members' teaching and research contribute to the mission of their departments and institutions, especially when that work challenges dominant disciplinary methods and narratives, as work in some less frequently taught languages and in literatures of people of color almost necessarily do. I think here not specifically of languages that fit the definition of less commonly taught languages but of languages with fraught political histories that have not been prominent in most departments of foreign languages in the United States, such as Arabic, Basque, Catalan, or Haitian Creole.

Scholarship and teaching in race and ethnicity and in less frequently taught languages and cultures (to cite only two areas of particular concern) that challenge normative disciplinary accounts of history or literature are especially vulnerable to weaknesses in the system of academic freedom for at least three reasons. First, scholarship and teaching that apply innovative methods in these areas often cut to the quick of triumphalist national narratives that are cherished by those who have benefited most from them or whose identities are intimately bound up with them. For this reason, emotions run high and can trounce commitments to the pursuit of knowledge. Second, the very scholarly norms that appropriately enforce disciplinary rigor may also be used to punish radically heterodox methods that reenvision a field. When more or less unconscious racist or nationalist attitudes are activated through the catalytic invocation of scholarly rigor, otherwise well-meaning people may believe that they are acting in the best interest of professional standards when they describe sound new scholarship as biased, essentialist, peripheral, minor, obscure, or, perhaps most damning, insufficiently theorized - all terms that I take to be coded put-downs as they are sometimes applied to scholarship on literatures of people of color and in lesser taught languages. Other coded terms and phrases include unsophisticated, narrow, not objective, minor, and does not make a significant contribution to the field. Scholars may be said to work on an incoherent archive of too-personal interest. Scholars of color themselves may be euphemistically judged uncollegial or not a good fit. ${ }^{1}$ Third, scholars who work in race and ethnic studies and in some languages are more likely than those working in, say, the American Renaissance or twentieth-century French literature to take up authors and subjects that are unfamiliar to their colleagues, students, and the wider public and to publish the results of their research in venues of lesser renown. In some people's minds, these new areas of scholarly expression are disruptive parvenus they've never heard of, and in the academy's prestige economy, big-name recognition matters: names of authors, references, journals, presses, scholars, schools, theories. We should take care not to conflate prominence with rigor or unfamiliarity with lack of rigor.

The foregoing are structural ways in which new scholarship may be less privy to the protections of academic freedom or more vulnerable to its weaknesses. I also want to mention an atmospheric problem: the unwelcoming climate reported by many faculty members of color, queer faculty members, and others. Unpleasant climates can exist because of prejudice, ignorance, and insensitivity. But the overall climate problem in departments that place a premium on research may result not only from what we usually term racism or nationalism - that is, more or less conscious prejudice-but also in important and poorly appreciated ways from individuals' 
Academic Freedom:

Norms, Methods,

Contestations

Doug Steward intense focus on their own work. This phenomenon goes by a number of names, one of the most common for younger scholars being overprofessionalization, by which I think we mean the single-minded pursuit of narrow specialization with a view to meeting the ever-escalating demand that younger scholars publish in order to be hired, tenured, and promoted. In extreme instances, individuals' pursuit of publications may supplant sound curricular design as the principle by which course offerings are determined: faculty members teach whatever they happen to be writing about, and the department's offerings become a patchwork of idiosyncratic research projects that make for an easy target when critics of the academy are looking for incoherent curricula as examples of the faculty's alleged abdication of responsibility. Incoherent curricula may be much rarer than some commentators on higher education would lead us to believe, but highly specialized faculty research agendas are not uncommon.

This atomization of faculty work can create alienating environments for everyone and disorienting curricula for students, but it has disproportionate effects on those working in areas that are less prominently featured in curricula. This may be the case for literatures by people of color in any language, whose subject matter may be inserted into the curriculum in highly inorganic fashion because a critical mass of other department members do in fact see ethnic literatures as an add-on rather than an organic part of the curriculum or do not know ethnic literatures well enough to understand what an organic place in the curriculum would be for them. In addition, it's not uncommon for programs, rather than departmental majors, to host work on ethnic literatures. It may also be the case for those working in lesser taught languages, which have smaller enrollments and less institutional clout. The consequences are that these scholars may work at a disadvantage in both the climate and the curriculum of the department. Robert Schwartzwald addresses this issue in the particular context of atomized hiring: "resisting the temptation to simply represent others in our curricula," he writes, "is pedagogically dependent on resisting niche hiring. Instead, our programs are strengthened by hiring rhizomatically . . . : by developing clusters, or nodes, that bring together in multiple ways, for students and scholarship, what are traditionally seen as unique or discrete traditions and literary objects" (37). The same might be said of curriculum design, which requires that all faculty members understand how and why the major fits together in a form that may be more rhizome than ivory tower. Let me emphasize in closing that non-tenure-track faculty members often have little input on the curricula in which they teach and may also lack appropriate control over the way they teach their courses: these should be core rights of academic freedom for faculty members, and the academic freedom of the department as a corporate body is undermined when they are not. The growth in reliance on non-tenure-track academic labor makes acute the question of academic freedom for non-tenure-track faculty members. The construction of curricula invulnerable to abridgments of academic freedom requires the responsible participation of the whole faculty so that the place of contestatory teaching and research can play their vital role in the critique of received knowledge and the literary archives grounding it. 
Academic Freedom:

Norms, Methods,

Contestations

Doug Steward
Note

1. My thanks to the members of the MLA Committee on the Literatures of People of Color for these euphemistic terms.

\section{Works Cited}

American Association of University Professors. "1940 Statement of Principles on Academic Freedom and Tenure.” American Association of University Professors. AAUP, 1990. Web. 15 Nov. 2010.

Hofstadter, Richard. The Age of the College. The Development of Academic Freedom in the United States. By Hofstadter and Walter P. Metzger. New York: Columbia UP, 1955. 1-274. Print.

Post, Robert. "The Structure of Academic Freedom." Academic Freedom after September 11. Ed. Beshara Doumani. New York: Zone, 2006. 61-106. Print.

Schwartzwald, Robert. "Lines Drawn and Redrawn: How Does the National Matter?" ADE Bulletin 146 (2008): 33-37. Web. 31 Jan. 2011.

Scott, Joan. "Academic Freedom as an Ethical Practice." The Future of Academic Freedom. Ed. Louis Menand. Chicago: U of Chicago P, 1996. 163-80. Print.

Steward, Doug. “Taking Liberties: Academic Freedom and the Humanities.” Profession (2008): 146-71. Print. 